Acta Theriologica 44 (4): 421-428, 1999.

PL ISSN 0001-7051

\title{
Iberian wild cat Felis silvestris tartessia predation on rabbit Oryctolagus cuniculus: functional response and age selection
}

\author{
Jose M. GIL-SÁNCHEZ, Gerardo VALENZUELA and Jose F. SÁNCHEZ
}

Gil-Sánchez J. M., Valenzuela G. and Sánchez J. F. 1999. Iberian wild cat Felis silvestris tartessia predation on rabbit Oryctolagus cuniculus: functional response and age selection. Acta Theriologica 44: 421-428.

Functional response and prey age selection have been studied for predator-prey relationships between the Iberian wild cat Felis silvestris tartessia Miller, 1907 and the rabbit Oryctolagus cuniculus (Linnaeus, 1758) through the study of the seasonal wild cat's diet and variations in rabbit availability in south-east Spain. This prey formed $73.7 \%$ of the total consumed biomass and was negatively correlated with trophic diversity. The wild cat showed a functional response approximate to Holling's type 2, exhibiting a high dependence on rabbit. The age class preferred was that of the juvenile rabbit, the smallest age class, and such hunting behaviour may be considered to be opportunistic. Results are discussed within the context of the relationship between the great size of this wild cat subspecies and the body size of the principal Iberian prey in Mediterranean areas, the rabbit.

Department of Animal Biology and Ecology, Faculty of Sciences, Universidad of Granada, E-18071 Granada, Spain, e-mail: aquatica@goliat.ugr.es (JMGS); C/ Acacias 70, Urb. Monteluz, E-18210 Peligros (Granada), Spain (GV); Consejería de Medio Ambiente, Junta de Andalucía, E-18701 Granada, Spain (JFS)

Key words: Felis silvestris tartessia, Oryctolagus cuniculus, prey age selection, functional response, Spain

\section{Introduction}

The wild cat Felis silvestris Schreber, 1777 is a small felid species specialized on small mammal predation, mainly rodents, which form the main prey item in central Europe (Sládek 1962, Condé et al. 1972, Kožená 1990), similar to the other small species of the Felinae subfamily (Nowell and Jackson 1996). The Iberian Peninsula, and more specifically, the area south of the rivers Duero and Ebro, is occupied by an endemic form of wild cat, early considered as a subspecies $F$. s. tartessia Miller, 1907. Independent of the taxonomic recognition, the Iberian wild cat is different both in coat pattern and, more especially, in body and teeth sizes, being larger than the European subspecies F. s. silvestris Schreber, 1777 (García-Perea et al. 1996). In this sense, the Iberian wild cat does not follow Bergmann's rule of increasing body size with latitude.

The limited research existing on the Iberian wild cat's diet demonstrates that the rabbit Oryctolagus cuniculus is an important prey item of this predator 
(Aymerich et al. 1980, Aymerich 1982, Sarmento 1996). Within this context, the large body size of the Iberian wild cat may be an adaptation for rabbit predation, a prey species significatively larger than the rodents normally captured in Europe, mainly Microtus. This type of adaptation has been suggested for other carnivore mammals which do not follow Bergmann's rule (Rosenzweig 1966, Erlinge 1987, Reig 1992).

The objective of this work was to study the prey selection and the prey size fitting in the relationship between the Iberian wild cat and the rabbit, through the study of functional response and prey age selection.

\section{Material and methods}

\section{Study area}

The study area was located in the eastern Subbetics mountains (SE Spain), on the western slope of the Sierra de Huétor Nature Park ( $\left.37^{\circ} 17^{\prime} \mathrm{N}, 3^{\circ} 39^{\prime} \mathrm{E}\right)$. The study area covers 3500 ha at an elevation of 650-750 m a.s.l. The area was covered by olive tree Olea europaea cultivations $(70 \%)$, where mesomediterranean holm oak Quercus ilex small forests (10-250 ha) are isolated remnants of the original forest. The study area was bisected by a river and two small streams, covered by a riparian forest well conserved with Populus alba, Ulmus minor, Salix alba and Tamarix gallica. The land-use of the forests was game management. Further information about climatic and vegetation types can be found in Rivas-Martínez (1986).

The wild cat population belongs to an important population of the Subbetic mountains and the approximate density of the study area was 0.5 individuals $/ \mathrm{km}^{2}$ (J. M. Gil-Sánchez, G. Valenzuela and M. Moleón, in prep.).

\section{Wild cat diet}

The wild cat's diet was obtained by analysis of 189 faeces (see Hewson 1983 for identification details), collected from February 1997 to January 1998. The same route of $7,125 \mathrm{~km}$ in the study area was travelled at the end of every sampling month. Prior to the sampling period a cleaning trip was carried out at the end of January 1997.

The analysis of faeces was carried out according to Delibes (1980) and Beltrán and Delibes (1991). In summary, each scat was soaked in water and components were separated by thorough washing in a sieve $(0.5 \mathrm{~mm}$ mesh), dried, and then prey species were identified by macroscopic analysis. The minimum number of each prey species in the faeces, primarily rodent, was calculated on the basis of bone remains such as mandibles and teeth. Biomass ingested was calculated according to the weight of each prey species given by Aymerich (1982). Three age classes were considered for the rabbit: juveniles, subadults and adults. The age classes were determined by comparing the size of the different bones that appeared in the faeces, with a collection of rabbits obtained in the study area. Teeth and forefoot bones were those used predominantly according to Calzada and Palomares (1996) who consider these the most suitable skeletal elements to estimate the age of consumed rabbits. The biomass consumed of each age class was assumed to be $250 \mathrm{~g}$ for the juveniles (Donázar 1989) and $400 \mathrm{~g}$ for subadults and adults (Aymerich 1982). For individuals of undetermined age, a biomass of $325 \mathrm{~g}$ was assumed.

Overall diet was estimated from the frequency of occurrence of prey types in each faecal sample, and percentage of consumed biomass (Corbet 1989) for each of the following prey categories: rabbits, small Muridae (Apodemus sylvaticus and Mus spretus), large rodents (Rattus sp., Arvicola sapidus and Eliomys quercinus), other small mammals (unidentified species and Crocidura russula), birds and reptiles.

\section{Rabbit availability}

The rabbit seasonal variations were calculated from a road count by jeep (Burnham et al. 1980, Soriguer 1981) well representative of the study area, which crossed the two principal habitats: olive 
tree cultivations $(575 \mathrm{~m})$, forests $(500 \mathrm{~m})$ and their ecotones $(775 \mathrm{~m})$. Six samplings were carried out for each month (except February and July, with five) after sunset, together with sunrise, the period of maximum rabbit activity (Soriguer 1981). During census as well as during the scat sampling trips, all observed rabbits were assigned to an age class on the basis of body size: juvenile, subadult or adult.

\section{Data analysis}

Significant seasonal differences in frequency of occurrence and biomass were tested for the Friedman two-way analysis of variance by ranks (Palomares 1993). Data was bimonthly grouped to obtain a sufficient sample size for a detailed seasonal analysis. The form of the functional response of the wild cat was examined by a representation of both occurrence and biomass frequencies of rabbit in diet, with the abundance of the rabbit as mean number of observed individuals during jeep sampling, by two months.

The age selection of rabbit was tested using a goodness of fit $G$-test on contingency tables (Manly et al. 1993). The bonferroni confidence intervals to control the experimentwise error probability at $p=0.05$ were used (Palomares 1993). Seasonal age class availability was compared with the wild cat's consumption of each age class by the wild cat. Samples were pooled into three seasonal periods: spring (March, April and June), summer (July, August and September) and autumn-winter (October to February) which were considered together given the low sample size.

\section{Results}

The diet of the wild cat was composed primarily of rabbit and secondly of mice (Table 1). The Friedman test detected significant differences among months $\left(\chi^{2}=21.16, \mathrm{df}=5, p<0.001\right.$ for frequency of occurrence and $\chi^{2}=20.64, \mathrm{df}=5$, $p<0.001$ for biomass), mainly due to a decreasing of rabbits and an increasing amount of mice, large rodents and birds during the final four months. Reptiles were consumed only during spring and summer (Fig. 1). A significative relationship was seen to exist between the occurrence frequencies of rabbit and large rodents $(r=-0.979, \mathrm{df}=5, p=0.0007)$.

Rabbit numbers varied throughout the year, with an important peak at the end of spring, followed by a dramatic fall during summer (Fig. 2). Table 2 shows the seasonal variations of the age classes. Juveniles and subadults appeared primarily during spring when the main annual reproduction occurs.

The functional response of the Iberian wild cat was close to a convex curve (Fig. 3) of type 2 (Holling 1959). This curve leveled off during the first eight months, overlapping both with the maximum annual levels of rabbits between June and July, and the decreasing rabbit number between August and November. It was only during the last two months that the rate of wild cat predation on rabbit experienced a significant drop.

Table 1. Overall diet composition of the wild cat in the Subbetic mountains. \%n - minimum number of individuals, $\% \mathrm{~F}$ - frequency of occurrence and $\% \mathrm{~B}$ percentage of consumed biomass.

\begin{tabular}{lrrr}
\hline & $\% n$ & $\% \mathrm{~F}$ & $\% \mathrm{~B}$ \\
\hline Rabbit & 28.1 & 64.0 & 73.72 \\
Small Muridae & 55.1 & 51.8 & 8.34 \\
Large rodents & 6.9 & 15.8 & 9.24 \\
Other small mammals & 3.4 & 7.9 & 0.39 \\
Birds & 3.4 & 7.9 & 4.40 \\
Reptils & 2.7 & 6.3 & 3.88 \\
$n$ & 430 & 189 & \\
\hline
\end{tabular}



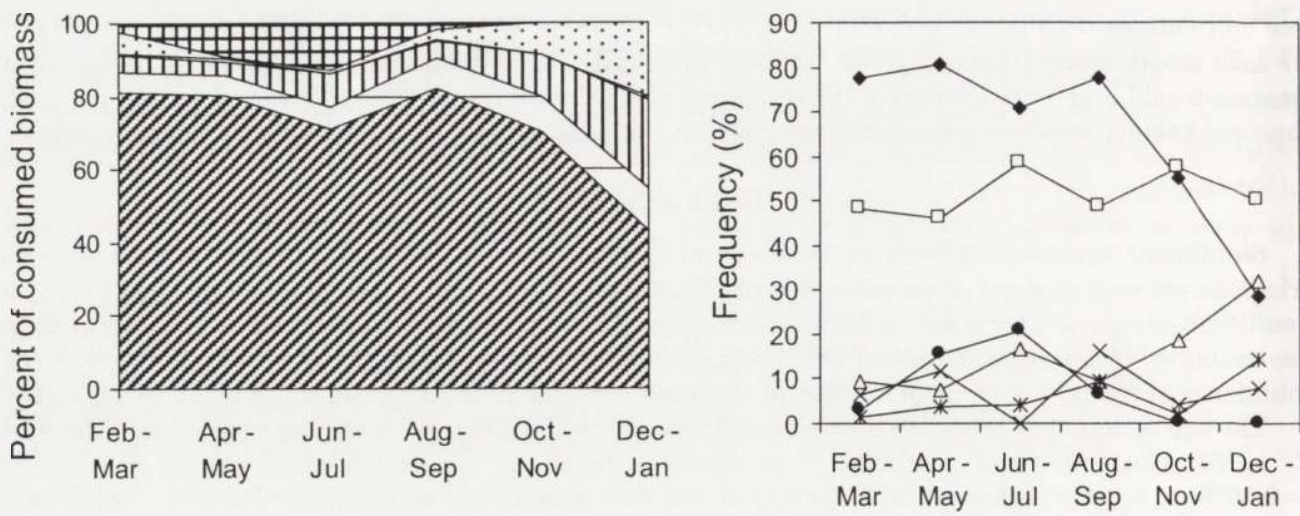

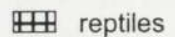

III) large rodents

$\downarrow$ rabbit

$*$ other small mammals

$\because \because$ birds

$\rightleftarrows$ small muridae

$\rightarrow$ - small muridae $\rightarrow$ birds

other small mammals

(7) rabbit

$\triangle$ large rodents $\rightarrow$ reptiles

Fig. 1. Bimonthly percent of consumed biomass (left) and frequency of occurrence in scats (right) of each prey-class by Iberian wild cats at Subbetic mountains.

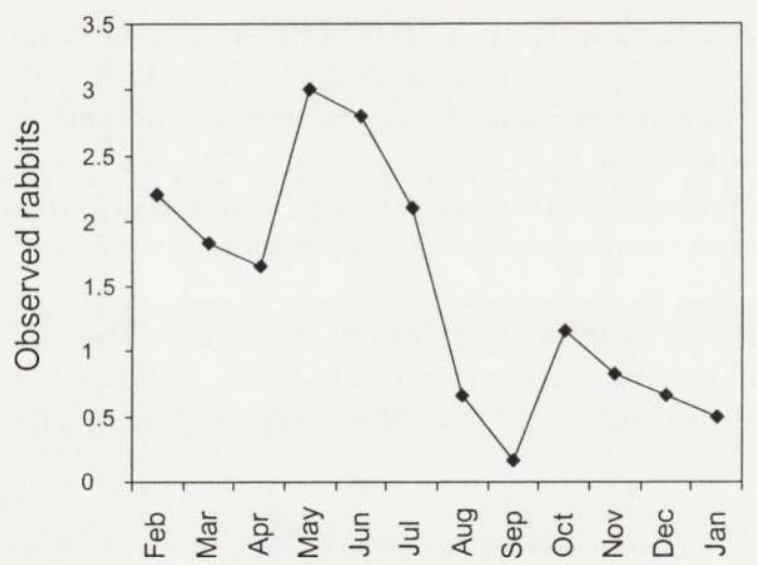

Fig. 2. Annual population pattern of rabbits in the study area. Mean numbers of observed rabbits from the road counts are shown.

Table 2. Seasonal composition of rabbit age classes (observed individuals during field sampling),

\begin{tabular}{lcccc}
\hline \multirow{2}{*}{ Season } & $n$ & \multicolumn{3}{c}{ Percent } \\
\cline { 3 - 5 } & & Adults & Subadults & Juveniles \\
\hline Spring & 99 & 48.5 & 30.3 & 21.2 \\
Summer & 71 & 53.5 & 33.8 & 12.7 \\
Autumn & 31 & 96.7 & 0.0 & 3.23 \\
Winter & 40 & 77.5 & 10.0 & 12.5 \\
$n$ & 241 & 147 & 58 & 36 \\
\hline
\end{tabular}



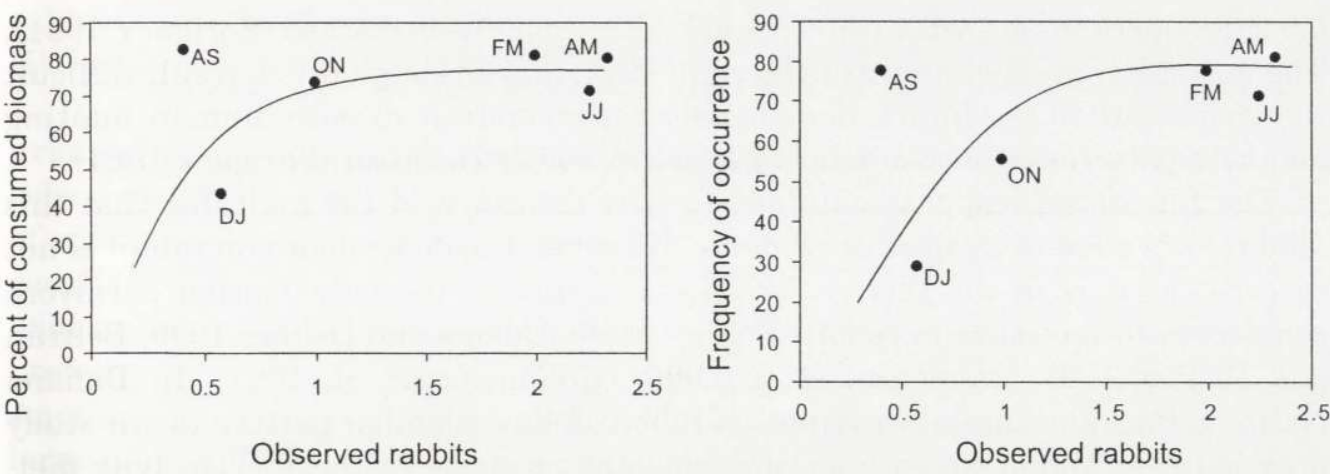

Fig. 3. Curves of the functional response of the Iberian wild cat to changes in the rabbit population, as percent of consumed biomass (left: $y=7.01 \ln x+67.86, R^{2}=0.14$, n.s.) and frequency of occurrence (right: $y=13.46 \ln x+57.93, R^{2}=0.29$, n.s.). FM - February-March 1997, AM - April-May 1997, JJ June-July 1997, AS - August-September 1997, ON - October-November 1997, and DJ - December 1997 - January 1998.

Fig. 4. Seasonal selection of rabbit age classes by the Iberian wild cat. Percentages of use and availability are shown; ${ }^{*}-p<$ $0.01 / 2 \mathrm{k}$, where $\mathrm{k}$ is equal to the number of age classes.

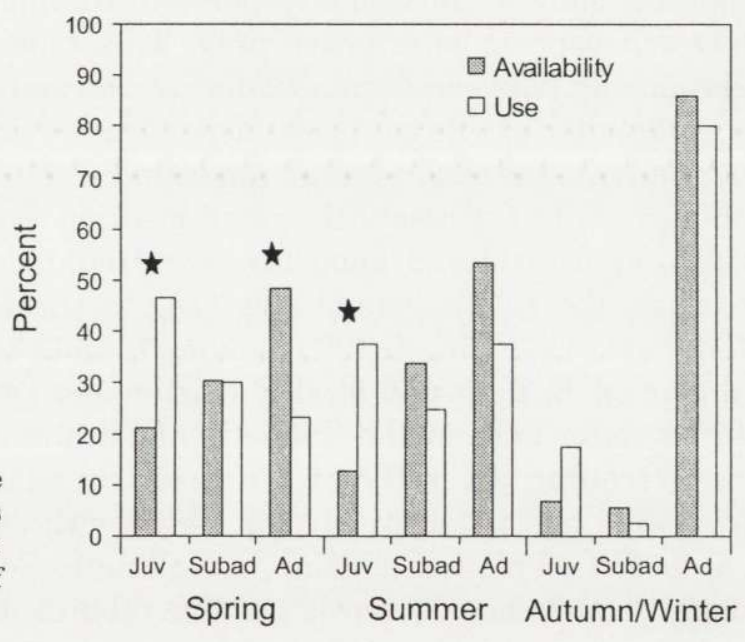

Juveniles were the only age class selected during spring-summer, whereas adults were negatively selected and subadults were taken in proportion to availability. During autumn-winter there was no clear age selection (Fig. 4).

\section{Discussion}

The diet of the wildcat was very similar to that known previously for central Spain (Aymerich 1982). The observed annual variations of rabbit abundance followed the characteristic pattern in Southern Spain (Delibes 1980). This pattern is correlated with the rain periods, which limit the pastures, an important resource 
for reproduction, and with the outbreak of myxomatosis disease (Soriguer 981). The autumn reproduction was delayed in 1997, and although it is a result dificult to explain due to the interactions between myxomatosis disease, human hunting and rain patterns, it is also a normal fact in Southern Spain (Soriguer 198])

The functional response obtained for the Iberian wild cat indicates tha this felid is very close to a selective predator. However, the dependence on rabbit s not so great as it is in the Iberian lynx Lynx pardinus, the only Iberian carrivore considered to specialize in rabbit (Delibes 1980, Aldama and Delibes 1990, Błltrán and Delibes 1991, Palomares et al. 1995, Gil-Sánchez et al. 1997). In Dinana National Park the annual variations of rabbits follow a similar pattern to our study area, and the rabbit has a high and constant presence in the Iberian lynx diet, among $80-90 \%$ of biomass frequency (Delibes 1980). Selective carnivores slow a functional response of type 2 because their diet is based on very few or, indeec only one prey species, which they kill even during the lows of prey populations, as happens in the relationship between the lynx Lynx lynx and the snowshoe hare Lepus americanus (Keith et al. 1977). On the other hand, opportunistic carnvores generally show a functional response of Holling's type 3, a sigmoid curve, beause they can capture alternative prey. This type of response was observed in the relationship between coyote Canis latrans and hares (Keith et al. 1977).

Although the wild cat is less dependent on rabbit than a pure specialist like the Iberian lynx, the rabbit has an important roll in the cat's diet, and especially $\mathrm{f}$ it is compared with the rest of the small-medium size sympatric carnivores of Souhern Spain, all considered opportunistic predators. Considering the percentage of biomass, the rabbit contributes 53\% to the fox Vulpes vulpes diet in Denana National Park (Fedriani 1996), among 10-60\% to the Egyptian mongoose Herpestes ichneumon in the same locality (Palomares 1993), and $14 \%$ to the stone marten Martes foina here in the Subbetic Mountains (Gil Sánchez 1996). On the other hand, trophic diversity of biomass (calculated through $H^{\prime}$ Shannon index: $\left.H^{\prime}=-\Sigma \mathrm{p}_{\mathrm{i}} \mathrm{Lnp}_{\mathrm{i}}\right)$ is negatively correlated with rabbit biomass $(r=-0.997, \mathrm{df}=5$, $p=0.0004$ ). This relationship, according to Schoener (1971) and Delibes (1980), suggests a tendency towards positive rabbit selection.

According to optimal diet theory, prey types should be ranked in the diet according to their net nutritive value (see review by Stephens and Krebs 1986). This being the case, the smallest age class selection may be considered as ₹ non optimal foraging behaviour, since these classes have a lesser biomass contribition. However, a recent study on age selection carried out in Doñana National ?ark, shows that even the pure specialist in rabbit Iberian lynx, feed mainly on not adult rabbits, nor even on emerged kittens (J. Calzada, unpubl.). In southern Sweden, feral cats took a much higher proportion of rabbits when young rabbits were abundant (Liberg 1984). The positive selection for young rabbits may be considered an opportunistic behaviour, as has been pointed out for the eagle owl Bubo bubo because this age class is easier to capture than the adult due to its inexperience (Donázar and Ceballos 1989). The Egyptian mongoose also captures more juvenile 
rabbits, but in this case it is due to the burrowing behaviour of the mongoose (Palomares and Delibes 1991).

In conclusion, the Iberian wild cat still selects rabbits despite the low seasonal availabilities, and the trophic position of the wild cat in the study area is closer to a selective carnivore as the Iberian lynx than to opportunistic carnivores. Increment of wild cat body size is an important help when it comes to capturing rabbits. Our results thereby would be following the initial hypothesis. Another large form of the wild cat, the Scottish wild cat $F$. s. grampia Miller, 1907, also has a great rabbit preference, $71.7 \%$ of occurrence in 224 wild cat scats examined by Corbet (1979). Another data that supports the size hypothesis for the Iberian wild cat is the use of large rodents as alternative prey, instead of the abundant mice, which shows higher frequencies than in central Europe where almost exclusively the wild cat captures smal rodents (Sládek 1962, Condé et. al. 1972, Kožená 1990).

Acknowledgements: We wish to thank Dr F. Palomares for some references as well as three anonymous reeferi for the valuable comments with respect to the initial version of this study, and for some interesting references. Tracy Smith kindly corrected our English.

\section{References}

Aldama J. J. and Delibes M. 1990. Some preliminary results on rabbit energy utilitation by the Spanish Lynx. Doñana Acta Vertebrata 17: 116-122.

Aymerich M. 1982. Etude comparative des régimenés alimentaires du lynx pardelle (Lynx pardina Tenmick, 1824) et du chat sauvage (Felis silvestris Schreber, 1777) au centre de la péninsule Iberique. Mammalia 46: 515-521.

Aymerich M., Palacios F., Garzón J., Cuesta J. and Castroviejo J. 1980. Sobre la alimentación del gato møntés (Felis silvestris Schreber, 1777) en Espan̄a. Actas I Reunión Iberoamericana de Zoología de Vettebrados, La Rábita 1977: 543-544.

Beltrán J. F. and Delibes M. 1991. Ecología trófica del lince ibérico en Doñana durante un periodo seco. Dōana Acta Vertebrata 18: 113-122.

Burnhm K. P., Anderson D. R. and Laake J. L. 1980. Estimation of density from line transect sanpling of biological populations. Wildlife Monographies 72: 1-202.

Calzaca J. and Palomares F. 1996. Frecuencia de aparición de diferentes restos de conejo en exrementos de lince y zorro. Doñana Acta Vertebrata 23: 243-252.

CondéB., Nguyen-Thi-Thu-Cuc, Vaillant F. and Schauenberg P. 1972. Le regime alimentaire du chat forstier ( $F$. silvestris Schr.) en France. Mammalia 36: 112-119.

Corbet L. K. 1979. Feeding ecology and social organization of wild cats (Felis silvestris) and domestic cat (Felis catua) in Scotland. Ph D thesis, University of Aberdeen, Aberdeen: 1-296.

CorbetL. K. 1989. Asessing the diet of dingoes from feces: a comparasition of 3 methods. The Journal of Nildlife Management 53: 342-346.

Delibe: M. 1980. El lince ibérico. Ecología y comportamiento alimenticios en el Coto Doñana, Huelva. Doiana Acta Vertebrata 7: 1-128.

Donáz:r J.A. 1989. Variaciones geográficas y estacionales en la alimentación del Bœho Real (Bubo buio) en Navarra. Ardeola 36: 24-40.

Donázir J. A. and Ceballos O. 1989. Selective predation by Eagle Owls Bubo bubo on rabbits Orctolagus cuniculus: Age and sex preferences. Ornis Scandinavica 20: 117-122.

GarcíaPerea E., Baquero R., Fern-Salvador R. and Gisbert J. 1996. Desarrollo juvenil del cráneo en las pollaciones ibéricas del gato montés, Felis silvestris Schreber, 1777. Doñana Acta Vertebrata 23: $15:-164$. 
Gil Sánchez J. M. 1996. Dieta de la garduña (Martes foina Erxleben, 1777) en una localidad de las sierras Subbéticas de Granada (Sureste de España). Doñana Acta Vertebrata 23: 83-90.

Gil-Sánchez J. M., Molino Garrido F. and Valenzuela Serrano G. 1997. Nota sobre la alimentación del lince ibérico en el Parque Natural de la Sierra de Andújar (Sierra Morena Oriental). Doñana Acta Vertebrata 24: 204-206.

Erlinge S. 1987. Why do European stoats Mustela erminea not follow Bergmann's rule? Holartic Ecology 10: 33-39.

Frediani J. M. 1996. Dieta anual del zorro, Vulpes vulpes, en dos hábitats del Parque Nacional de Doñana. Doñana Acta Vertebrata 23: 143-152.

Hewson R. 1983. The food of wild cats (Felis silvestris) and red foxes (Vulpes vulpes) in west and north-east Scotland. Notes fron the Mammal Society 46: 283-289.

Holling C. S. 1959. Some characteristics of simple types of predation and parasitism. Canadian Entomologist 91: 385-398.

Keith L. B., Todd A. W., Brand C. J., Adamcik R. S. and Russh D. H. 1977. An analysis of predation during a cyclic fluctuation of snowhoe hares. XIII. International Congress of Game Biologists: $151-175$.

Kožená I. 1990. Contribution to the food of wild cat (Felis silvestris). Folia Zoologica 39: 207-212.

Liberg O. 1984. Food habits and prey impact by feral and house-based domestic cats in a rural area in Southern Swede. Journal of Mammalogy 65: 424-432.

Manly B., McDonald L. and Thomas D. 1993. Resource selection by animals. Statistical design and analysis for field studies. Chapman and Hall, London: 1-177.

Nowell K. and Jackson P. 1996. Wild cats. Status survey and conservation action plan. IUCN, Gland, Switzerland: $1-382$.

Palomares F. 1993. Opportunistic feeding of the Egyptian mongoose, Herpestes ichneumon, (L.) in southwestern Spain. Revue D'Ecologie (Terre Vie) 48: 295-304.

Palomares F. and Delibes M. 1991. Dieta del meloncillo, Herpestes ichneumon, en el Coto del Rey (Norte del Parque Nacional de Doñana, S.O. de España). Doñana Acta Vertebrata 18: 187-194.

Palomares F., Gaona P., Ferreras P. and Delibes M. 1995. Positive effects on game species of top predators by controlling smaller predator populations: An example with lynx, mongooses and rabbits. Conservation Biology 9: 295-305.

Reig S. 1992. Geographic variation in pine marten (Martes martes) and beech marten (M. foina) in Europe. Journal of Mammalogy 73: 744-769.

Rivas Martínez S. 1986. Mapa de las Series de Vegetación de la Península Ibérica. Ministerio de Agricultura. Madrid.

Rosenzweig M. L. 1966. Community structure in sympatric Carnivora. Journal of Mammalogy 47: 602-612.

Sarmento P. 1996. Feeding ecoligy of the European wildcat Felis silvestris in Portugal. Acta Theriologica 41: 409-414.

Schoener T. W. 1971. Theory of feeding strategies. Annual Reviews of Ecology and Systematics 2: 369-404.

Sládek J. 1962. Vorläufige Angaben über Ernährung der Wildkatze (Felis silvestris) in der Slowakei auf Grund der Magenuntersuchungen. Symposium Theriologicum, Brno 1960, Praha: 286-289.

Soriguer R. 1981. Biología y dinámica de una población de conejos (Oryctolagus cuniculus) en Andalucía Oriental. Doñana Acta Vertebrata 8: 1-379.

Stephens D. W. and Krebs J. R. 1986. Foraging theory. Princeton University Press, Princeton New Jersey: 1-261.

Received 31 March 1998, accepted 15 March 1999. 